\title{
MONITORING CRITICAL INFRASTRUCTURE EXPOSED TO ANTHROPOGENIC AND NATURAL HAZARDS USING SATELLITE RADAR INTERFEROMETRY
}

\section{MONITORIZACIÓN DE INFRAESTRUCTURAS CRÍTICAS EXPUESTAS A RIESGOS NATURALES Y ANTRÓPICOS MEDIANTE INTERFEROMETRÍA RADAR DE SATÉLITE}

\author{
Antonio Miguel Ruiz-Armenteros ${ }^{\mathrm{a}, \mathrm{b}, *}$, José Manuel Delgado-Blasco ${ }^{\mathrm{a}}$, Matus Bakon ${ }^{\mathrm{c}, \mathrm{d}}$, Milan \\ Lazeckye,f, Miguel Marchamalo-Sacristáng , Francisco Lamas-Fernández ${ }^{\mathrm{h}}$, Ana Ruiz-Constáni, \\ Jesús Galindo-Zaldívari, Carlos Sanz de Galdeanok, Sergio Martos-Rosilloi, Juraj Papco', Daniele \\ Perissin ${ }^{m, n}$, Joaquim J. Sousa ${ }^{o, p}$ \\ ${ }^{a}$ Grupo de investigación Microgeodesia Jaén, Departamento de Ingeniería Cartográfica, Geodésica y Fotogrametría, Universidad de \\ Jaén, Campus Las Lagunillas s/n, Edif. A3, 23071 Jaén, Spain. amruiz@ujaen.es; jdblasco@ujaen.es \\ ${ }^{b}$ Centro de Estudios Avanzados en Ciencias de la Tierra (CEACTierra), Universidad de Jaén, 23071 Jaén, Spain \\ c insar.sk s.r.o., 08001 Presov, Slovakia. matusbakon@insar.sk \\ ${ }^{\mathrm{d}}$ Department of Environmental Management, University of Presov, 08001 Presov, Slovakia \\ e School of Earth and Environment, University of Leeds, Leeds, United Kingdom. M.Lazecky@leeds.ac.uk \\ f IT4Innovations, VSB-TU Ostrava, Ostrava, Czechia \\ g Topography and Geomatics Lab., ETS ICCP, Universidad Politécnica de Madrid, 28040 Madrid, Spain. miguel.marchamalo@ump.es \\ h Departamento de Ingeniería Civil, Universidad de Granada, 18071 Granada, Spain. flamas@ugr.es \\ ' Instituto Geológico y Minero de España, 18006 Granada, Spain. a.ruiz@igme.es; s.martos@igme.es \\ j Departamento de Geodinámica, Universidad de Granada, 18071 Granada, Spain, jgalindo@ugr.es \\ k Instituto Andaluz de Ciencias de la Tierra (CSIC-UGR), 18071 Granada, Spain, csanz@ugr.es \\ ' Department of Theoretical Geodesy, Slovak Technical University STU Bratislava, Slovakia. juraj.papco@stuba.sk \\ ${ }^{\mathrm{m}}$ Raser Limited, Hong Kong, China. daniele.perissin@sarproz.com \\ ${ }^{n}$ CIRGEO, Università degli Studi di Padova, Padova, Italy \\ 。 Universidade de Trás-os-Montes e Alto Douro, Vila Real, Portugal. jjsousa@utad.pt \\ p INESC Technology and Science (INESC-TEC), Universidade do Porto, 4200-465 Porto, Portugal
}

\begin{abstract}
:
Synthetic Aperture Radar Interferometry (InSAR) is a remote sensing technique very effective for the measure of small displacements of the Earth's surface over large areas at a very low cost as compared with conventional geodetic techniques. Advanced InSAR time series algorithms for monitoring and investigating surface displacement on Earth are based on conventional radar interferometry. These techniques allow us to measure deformation with uncertainties of 1 $\mathrm{mm} /$ year, interpreting time series of interferometric phases at coherent point scatterers (PS) without the need for human or special equipment presence on the site. By applying InSAR processing techniques to a series of radar images over the same region, it is possible to detect line-of-sight (LOS) displacements of infrastructures on the ground and therefore identify abnormal or excessive movement indicating potential problems requiring detailed ground investigation. A major advantage of this technology is that a single radar image can cover a major area of up to $100 \mathrm{~km}$ by $100 \mathrm{~km}$ or more as, for example, Sentinel-1 C-band satellites data cover a $250 \mathrm{~km}$ wide swath. Therefore, all engineering infrastructures in the area, such as dams, dikes, bridges, ports, etc. subject to terrain deformation by volcanos, landslides, subsidence due to groundwater, gas, or oil withdrawal could be monitored, reducing operating costs effectively. In this sense, the free and open access Copernicus Sentinel-1 data with currently up to 6-days revisit time open new opportunities for a near real-time land monitoring. In addition, the new generation of high-resolution radar imagery acquired by SAR sensors such as TerraSAR$\mathrm{X}, \mathrm{COSMO}-\mathrm{SkyMed}$, and PAZ, and the development of multi-interferogram techniques has enhanced our capabilities in recent years in using InSAR as deformation monitoring tool. In this paper, we address the applicability of using spaceborne SAR sensors for monitoring infrastructures in geomatics engineering and present several cases studies carried out by our group related to anthropogenic and natural hazards, as well as monitoring of critical infrastructures.
\end{abstract}

Key words: InSAR, deformation monitoring, PS-InSAR, geomatics, subsidence, natural hazards, anthropogenic hazards

*Corresponding Author: Antonio Miguel Ruiz-Armenteros, amruiz@ujaen.es 


\section{Resumen:}

La interferometría radar de apertura sintética (InSAR) es una técnica de teledetección muy eficaz para medir pequeños desplazamientos de la superficie terrestre en grandes áreas a un coste muy pequeño en comparación con las técnicas geodésicas convencionales. Los algoritmos avanzados de series temporales InSAR para monitorizar e investigar el desplazamiento de la superficie terrestre se basan en la interferometría radar convencional. Estas técnicas nos permiten medir la deformación con incertidumbres de un milímetro por año, interpretando series temporales de fases interferométricas en retrodispersores puntuales coherentes (PS) sin necesidad de presencia humana o de equipos especiales en el sitio. Al aplicar técnicas de procesamiento InSAR a una serie de imágenes radar de la misma región, es posible detectar desplazamientos de infraestructuras proyectados en la línea de vista del satélite (line-of-sight o LOS) y, por lo tanto, identificar movimientos anormales o excesivos que indiquen problemas potenciales que requieran una investigación detallada del terreno. Una de las principales ventajas de esta tecnología es que una sola imagen radar puede cubrir un área importante de hasta $100 \mathrm{~km}$ por $100 \mathrm{~km}$ o más, ya que, por ejemplo, los datos de los satélites de banda $\mathrm{C}$ Sentinel-1 cubren una franja de $250 \mathrm{~km}$ de ancho. Por lo tanto, todas las infraestructuras civiles de la zona, como presas, diques, puentes, puertos, etc., sujetas a deformaciones del terreno por actividad volcánica, deslizamientos de tierra, hundimientos por extracción de agua subterránea, gas o petróleo, podrían ser monitorizados, reduciendo los costes operativos de manera efectiva. En este sentido, los datos Sentinel-1 de Copernicus, de acceso abierto, con hasta 6 días de tiempo de revisión actual abren nuevas oportunidades para una monitorización terrestre casi en tiempo real. Además, la nueva generación de imágenes radar de alta resolución adquiridas por sensores SAR como TerraSAR-X, COSMOSkyMed y PAZ, y el desarrollo de técnicas multi-interferograma ha mejorado nuestras capacidades en los últimos años en el uso del InSAR como herramienta para el control de deformaciones. En este trabajo se aborda la aplicabilidad del uso de sensores SAR espaciales para la monitorización de infraestructuras civiles en ingeniería geomática y presentamos varios casos de estudio realizados por nuestro grupo relacionados con riesgos naturales y antrópicos, así como de monitorización de infraestructura crítica.

Palabras clave: InSAR, control de deformaciones, PS-InSAR, geomática, subsidencia, riesgos naturales, riesgos antrópicos

\section{Introduction}

Due to natural causes and human activities, the ground surface is constantly in motion. Many measurement techniques have been developed over time to study the Earth's surface deformation. Some of them, besides having different levels of accuracy, are time-consuming (e.g., classical surveys). In addition to classical surveys, the introduction of space-geodetic techniques like GNSS and the interferometric use of Synthetic Aperture Radar (InSAR) have offered new opportunities for precise deformation monitoring in geomatics engineering. In particular, using the InSAR technique large areas can be monitored providing ground displacements at relatively low cost when compared to leveling, for example.

Spaceborne InSAR is a well-known technology that has matured to a more and more standard tool as geomatic technique for measuring and monitoring the Earth's surface. Its use in certain applications is triggering its use in others (Ferretti 2014). This technique allows precise surface deformation measurements on large areas and high spatial density of measurement points, being one of the fastest developing research fields in remote sensing (Zhong et al. 2010). InSAR relies on the processing of two SAR images of the same portion of the Earth's surface obtained either from two slightly displaced passes of the SAR antenna at different times (repeat-pass interferometry), or from two antennas placed on the same platform and separated perpendicularly to the flight path (single pass SAR interferometry). However, despite the many successes of InSAR, problems due to changes in the scattering properties of the Earth's surface with time as well as the incidence angle of the radar look direction limit the applicability of the technique. This makes detection of slow deformation processes in particular, challenging to detect by standard InSAR techniques.
In the late 1990s, it was noticed that some radar targets maintain stable backscattering characteristics for a period of months or years (Usai 1997; Usai and Hanssen 1997), and the phase information from these stable targets (hereafter called Persistent Scatterers or PS) can be used, even over a long time period, profiting from a SAR scene archive in existence since 1991 (ERS-1) which allows the establishment of long time series of SAR images. This led to the development of time series SAR interferometry methodologies or, as they are also known, multi-interferogram techniques, considered nowadays standard tools for deformation measurements due to their ability to overcome the limitations of the conventional InSAR.

\section{Spaceborne SAR Interferometry for remote monitoring of the Earth}

InSAR, also referred to as SAR Interferometry, is the measurement of signal phase change over time. In recent years, spaceborne repeat-pass InSAR has received much attention for its ability to generate deformation maps with unprecedented accuracy (centimetre or millimetre level). SAR achieves relatively good resolution using a small radar antenna, which is an important issue when dealing with satellites that must be limited in size and power consumption. To achieve this high resolution, SAR uses the motion of the single radar antenna along a flight path (or orbit) to form a "synthetic antenna" that is much larger than the actual one. This improves the resolution of the radar along the trajectory (azimuth direction). To achieve a high resolution in the across track, or range direction, the radar uses a frequency modulated waveform and pulse compression to simulate a very short pulse, hence a high-resolution echo.

It is clear that the difficulties related to the estimation of surface deformation signals from a single SAR interferogram are essentially due to the presence of 
decorrelation effects (contributing to the noise level), the impact of local topography on phase values and the presence of atmospheric phase components superimposed on the signal of interest. Unfortunately, using DInSAR, that is, a single interferogram, it is not possible to remove the atmospheric component. Thus, DInSAR should only be used on the understanding that deformation measurements are prone to errors arising from atmospheric circumstances. It can only measure total displacement between two points in time. Therefore, DInSAR is not able to distinguish between linear and nonlinear motion. However, it is a powerful technique in describing the deformation pattern in many cases in geosciences. Nowadays, few days after any important earthquake the scientific community is able to show how the Earth was deformed which helps in modelling the coseismic deformation (see Marinkovic and Larsen 2016 as example). Despite these limitations, in the last two decades, DInSAR techniques have been demonstrating their potential as surface deformation measurement tools.

Recently, the capability of the multi-interferogram techniques has been considerably improved by using large stacks of SAR images acquired over the same area (Hooper et al. 2012). The use of multi-image datasets enables the identification of stable reflectors, the previously referred to as PS, which are points on the ground that consistently return stable signals to the satellite radar sensor. These PS allow ground displacement velocities to be measured with millimeter accuracy (Marinkovic et al. 2008; Adam et al. 2009; Peltier et al. 2010; Ferretti et al. 2011). PS typically correspond to objects on man-made structures such as buildings, bridges, dams, water-pipelines, antennae, as well as to stable natural reflectors (e.g., exposed rocks).

Unlike optical systems that rely on reflected solar radiation or thermal radiation emitted by Earth, imaging radar instruments work independently of light and heat (Rosen et al. 2000; Hanssen 2001). Therefore, SAR sensors can provide day-and-night imagery of Earth independently of weather conditions. In the last three decades, with particular emphasis on the last one, various space agencies have undertaken missions for Earth observation with microwave SAR sensors. The main spaceborne SAR sensors used for deformation monitoring include the ERS-1/2, Envisat, and Sentinel$1 \mathrm{~A} / 1 \mathrm{~B}$ (C-band) from ESA (Europe), J-ERS-1, ALOS/PALSAR, and ALOS-2 (L-band) from JAXA (Japan), Radarsat-1 and Radarsat-2 C-band (CSA, Canada), TerraSAR-X and TanDEM-X (X-band) from DLR/Astrium (Germany), COSMO-SkyMed-1/4 constellation (X-band) from ASI/MiD (Italy), the Spanish PAZ (Hisdesat), and KOMPSAT-5 (X-band) (KARI, Korea). Among all of them, the Sentinel-1 is the first (civilian) sensor specifically designed for surface deformation monitoring over large areas with a free, full and open data policy adopted for the Copernicus programme.

The typical horizontal spatial resolution, obtained via current SAR satellites, ranges from 0.25 (e.g., TerraSAR$X$ in staring spotlight mode) to $150 \mathrm{~m}$, and resolutions typically used for InSAR are between 3 (even lower) and $30 \mathrm{~m}$. The high resolution SAR data of the new SAR sensors like TerraSAR-X, COSMO-SkyMed, PAZ, and Radarsat-2 increase significantly the level of details visible in the SAR images. The detection and mapping of buildings, city structures and infrastructure like roads and railways, dams, etc. is possible. These features are of interest for mapping and monitoring purposes.

Multi-interferogram techniques, as explained before, are extensions of conventional DInSAR aimed at addressing the problems caused by decorrelation and atmospheric delay. These techniques involve the simultaneous processing of multiple SAR acquisitions over the same area to allow for the correction of uncorrelated phase noise terms and hence, reduce errors associated with the deformation estimates. MT-InSAR is the collective term used within the InSAR community to distinguish between single interferogram DInSAR and the second generation of InSAR technologies. The first of these methods to appear, in 1999, was the Permanent Scatterer algorithm (PSInSAR ${ }^{\mathrm{TM}}$ ) (Ferretti et al. 2000, 2001). The interferogram is at the core of all MT-InSAR technologies and the main driver for their development was the need to overcome the errors introduced into signal phase values by atmospheric artifacts. These limitations are tackled by using phase behavior in time to select pixels where decorrelation noise is minimized. Then the nondeformation signal is estimated by a combination of modeling and filtering of the time series. The MT-InSAR algorithms fall into two broad categories, the first being Persistent Scatterer InSAR (PS-InSAR or PSI) and the second being the more general Small BASeline (SBAS) approach. Each of these sets of methods is designed for a specific type of scattering mechanism. PSI algorithms operate on a time series of interferograms all formed with respect to a single "master" SAR image. The detection of resolution cells exhibiting only small reflectivity changes is a key step in every PSI algorithm and is essentially done by assessment of the phase portion associated with noise. In order to isolate the phase noise, assumptions about the spatio-temporal behavior of all other phase contributions have to be made. While general principles apply for most of the phase contributions, the deformation often requires a specific modeling. In some approaches a functional time dependent model is assumed and fitted to the time series of every PS (Adam et al. 2003; Crosetto et al. 2003; Ferretti et al. 2001; Kampes 2005; Lyons and Sandwell 2003). Alternatively, one may assume the deformation to be spatially correlated (Hooper et al. 2004). Spatial filtering is applied to estimate the spatiallycorrelated terms, including the deformation, atmospheric, and orbit error phase, for each PS candidate. The spatially-correlated phase is subtracted and the residual contribution from DEM error in the remaining phase is modeled for the whole time series, with the residual between the phase and the model providing an estimate of the noise for the pixel. For resolution elements containing no dominant scatterer, phase variation due to decorrelation is often large enough to obscure the underlying signal. However, by forming interferograms only between images separated by a short time interval and with a small difference in look and squint angle, decorrelation is minimized, and for some resolution elements can be small enough that the underlying signal is still detectable. Pixels for which the filtered phase decorrelates little over short time intervals are the targets of SBAS methods (Berardino et al. 2002; Hooper 2008; Lanari et al. 2004). SBAS methods can achieve uncertainties similar to the PSI techniques, on the order of $\sim 1 \mathrm{~mm} /$ year (Lanari et al. 2007), although this again depends on the number of images, the time over which the images are acquired and the distance from the 
reference point or area. With the advent of an even more advanced MTI processing technique, that combines both PSI and SBAS methodologies (Hooper 2008; Ferretti et al. 2011; Perissin and Wang 2012a, 2012b) these sensors have been used to monitor deformation from a large array of natural and man-made structures including large scale structures such as dams and dikes. The several tests carried out using different types of structures have served to establish standard procedures for structures monitoring using interferometric techniques and allowed to conclude that C-band, despite its coarse spatial and temporal resolutions (Sentinel- 1 is considerably improved this status), is capable of being used in monitoring major structures, including dams.

Regardless of the method used, all measurements are made in the satellite line-of-sight or LOS direction, that is, only the projection of the 3D ground deformation along the LOS direction can be measured. Furthermore, this technique only provides relative mesurements referred spatially to a reference point or stable area selected in the processing crop, and temporally to a specific acquisition date inside the analyzed dataset. Only if ascending and descending data are available over the processed area in the same time windows, truly vertical and East-West displacements can be separately resolved. Once the data have been analyzed, it is possible to develop the history of movement across the area of interest (time series of deformation). This is achieved by sequentially calculating the relative displacement between an individual radar target and the reference point, throughout the entire period of the analysis. Thus, the deformation is relative in time and space. Much research has been done to study the accuracy, potentials and limitations of this technique with respect to a large variety of applications. Crosetto et al. (2016), Osmanoğlu et al. (2016) and Ho Tong Minh et al. (2020) offer a review of these multi-interferograms algorithms.

In conclusion, monitoring methods have different features and should be used in different situations. Airborne and spaceborne methods should be used for systematic monitoring of civil infraestructures, and in case of a suspicious results, more sensible/accurate methods should be used (sensors, ground-based methods, leveling), depending on the nature of the problem.

\section{Case studies}

In this section we present some case studies performed by the authors to show the feasibility of MT-InSAR and where this techonology has been successfully applied for monitoring some areas and infrastructures.

\subsection{Dam monitoring}

As a first case study, we show the feasibility of MT-InSAR tecniques to dam deformation monitoring. These case studies belong to the ReMoDams initiative, a research Spanish project devoted to the application of MT-InSAR techniques for monitoring the structural stability of embankent dams from space using satellite radar data.

\subsubsection{La Viñuela dam (Malaga, Spain)}

The Reservoir of La Viñuela is located on the Guaro River, in the municipality of La Viñuela (province of Málaga, southern Spain) (Fig. 1). It controls the waters of the hydrographic network of the region of La Axarquía and was built to supply drinkable water to the region, to improve the irrigated lands as well as flood lamination. The Guaro River is born in Periana and receives waters from its tributaries, the Sabar, Benamargosa, and Salia Rivers.

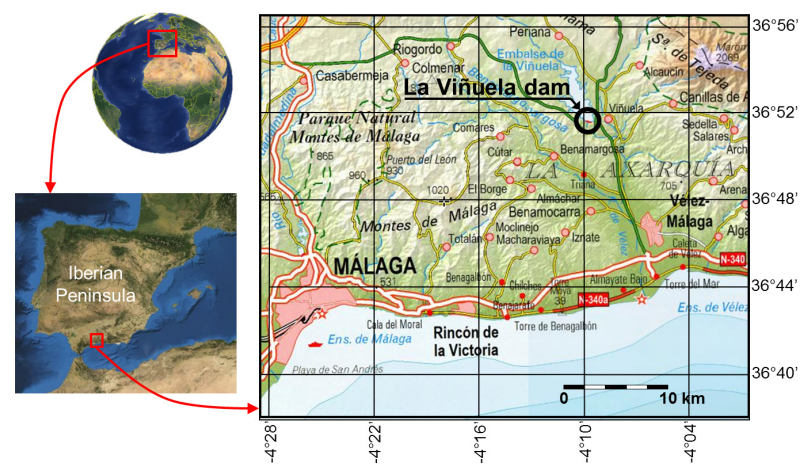

Figure 1: Location of La Viñuela dam in the province of Málaga (southern Spain).

The basin of La Viñuela reservoir has an own surface of $119 \mathrm{~km}^{2}$, an average yearly rainfall of $893 \mathrm{~mm}$ and an average yearly contribution of $25 \mathrm{~km}^{3}$. The reservoir is made of loose materials (embankment dam), having a coronation length of $460 \mathrm{~m}$, and heights of $96 \mathrm{~m}$ over foundations and of $90 \mathrm{~m}$ over the riverbed. It presents a chute spillway with frontal lobe in arch with a pouring length of $30 \mathrm{~m}$ and a maximum flow of $382 \mathrm{~m}^{3} / \mathrm{s}$. The bottom drainage consists of a detour tunnel with tow pipes discharging a maximum of $70 \mathrm{~m}^{3} / \mathrm{s}$. The Reservoir of La Viñuela has a surface of 565 ha and a capacity of 170 $\mathrm{hm}^{3}$. The construction of the dam started on October $22^{\text {nd }}$, 1982 and finished in 1989, although it filled completely first in 1998.

The dam was analyzed using C-band radar data $(\sim 5,7 \mathrm{~cm}$ wavelength) from the European satellites ERS-1/2, Envisat, and Sentinel-1A/B (Ruiz-Armenteros et al. 2018a). 24 SLC ERS-1/2 SAR images were used, corresponding to descending orbits (track 51) acquired between May $5^{\text {th }}, 1992$ and January $28^{\text {th }}, 2000$ with an incident angle of $23^{\circ}$ and a $5 \times 25 \mathrm{~m}$ nominal spatial resolution. Due to ERS-2 on-board gyroscope failure on January 2001, only images until the end of 2000 were selected to avoid high Doppler centroid differences of more than the critical value of $700 \mathrm{~Hz}$. The SLC Envisat ASAR dataset is composed of 27 images acquired from March $21^{\text {st }}, 2003$ to August $1^{\text {st }}, 2008$, along ascending orbits (track 459), with an incidence angle of $23^{\circ}$ at the middle swath IS2, and a $5 \times 25 \mathrm{~m}$ nominal pixel dimension. The Sentinel-1A/B SAR dataset is formed by 126 SLC IW images (86 Sentinel-1A and 40 Sentinel-1B) acquired in descending orbits from November $16^{\text {th }}, 2014$ to February $28^{\text {th }}, 2018$.

The ERS-1/2 and Envisat datasets were processed using StaMPS-MTI, combining the PSI and SBAS techniques. On the other side, Sentinel-1 data was processed using SARPROZ (Perissin 2015) and IT4S1 approach (ISCE+StaMPS/SALSIT) with the standard PSI technique.

Figure 2 shows the mean LOS velocity maps derived from StaMPS-MTI for ERS-1/2 (May 1992-January 2000) and Envisat (March 2003-August 2008) processing. In the 
case of ERS-1/2, a subsidence pattern can be clearly seen with maximum subsidence around $-7 \mathrm{~mm} /$ year on the dam crest. In the Envisat period, the subsidence pattern is lower, with maximum subsidence in the order of $-4 \mathrm{~mm} /$ year. Finally, for Sentinel-1 data, the standard PSInSAR approach from SARPROZ with the linear model assumption for the deformation estimates confirmed that the investigated area of the dam body is prone to subsidence of up to $-6 \mathrm{~mm} / \mathrm{year}$ (LOS velocity) in the whole monitoring period (November 2014 - February 2018) (Fig. 3).

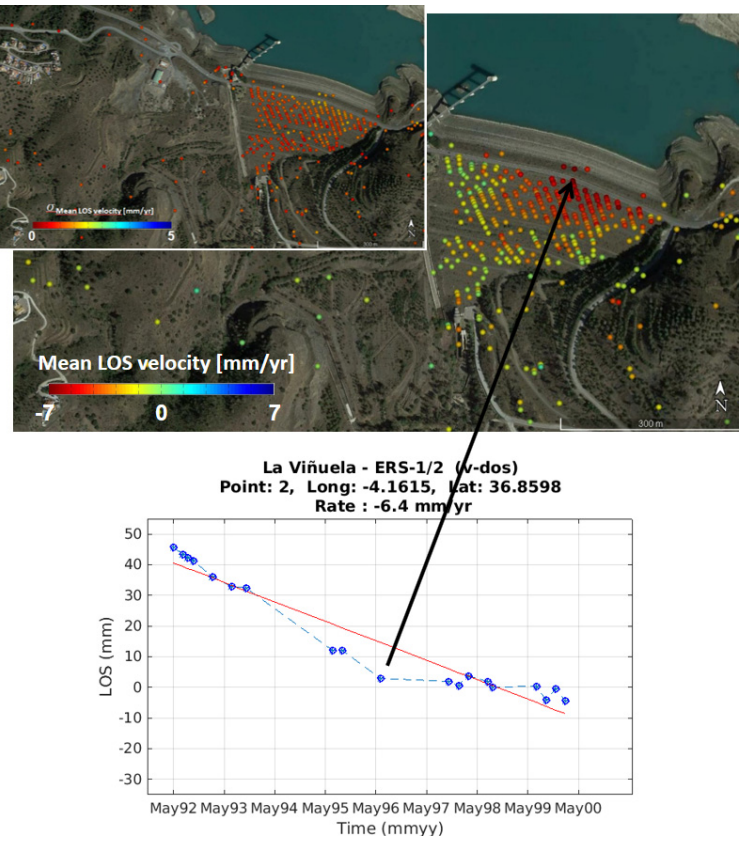

(a)

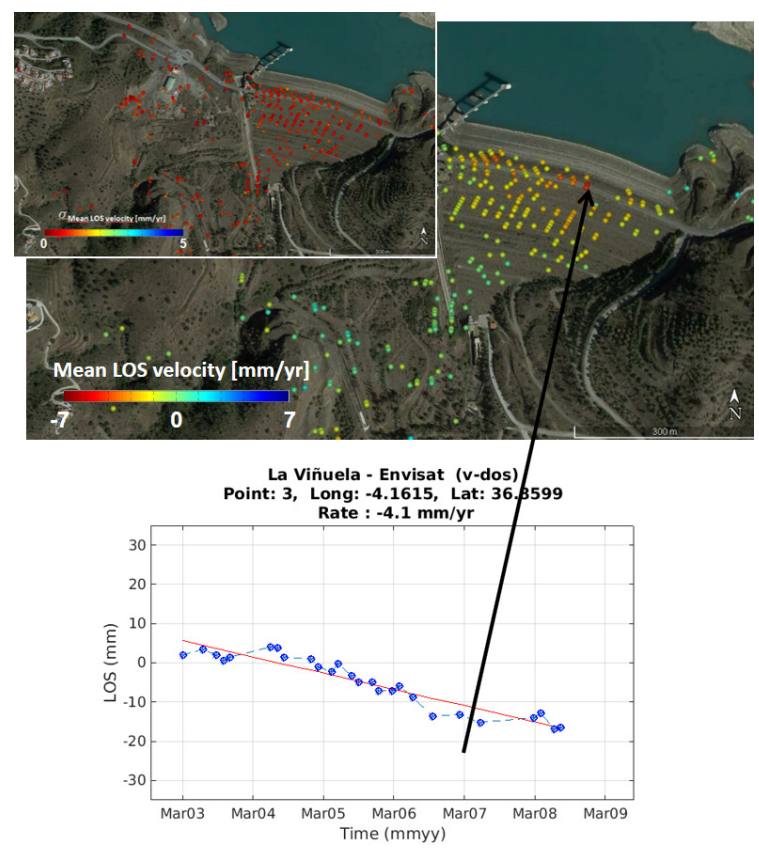

(b)

Figure 2: Mean LOS velocity and its standard deviation for

ERS-1/2 (1992-2000) (a) and Envisat (2003-2008) (b) processing. One time-series, representative of the deformation, is plotted for each processing.

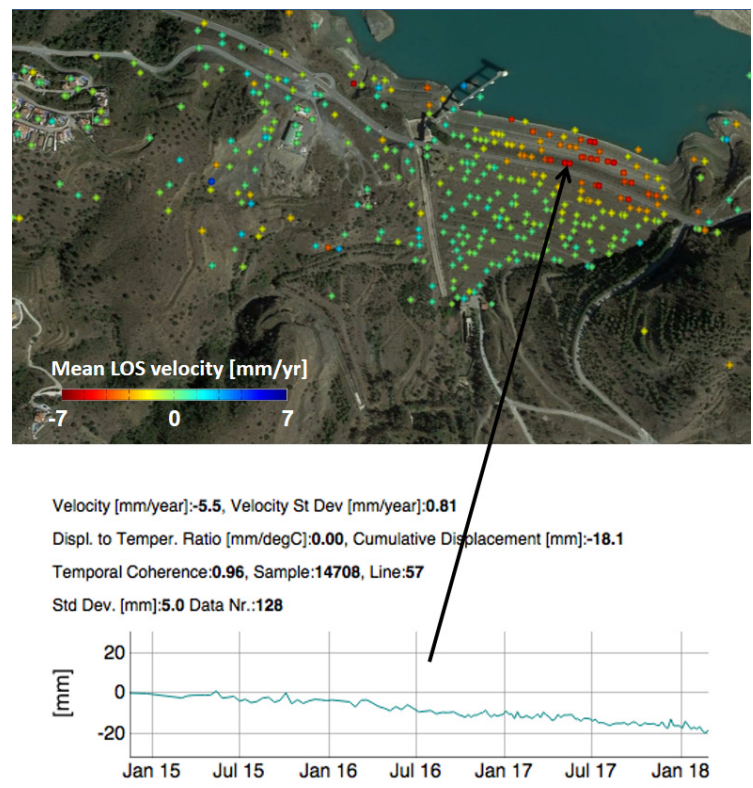

Figure 3: Mean LOS velocity for Sentinel-1A/B (2014-2018) processing using SARPROZ. One time-series representative of the deformation is plotted.

\subsubsection{El Arenoso dam (Cordova, Spain)}

The Arenoso dam (Montoro, Cordova, S Spain) is an embankment dam located in the Arenoso riverbed, a tributary of the Guadalquivir River with a capacity of 167 $\mathrm{hm}^{3}$ and a basin of $405 \mathrm{~km}^{2}$ (Fig. 4). The dam has a maximum height of $80 \mathrm{~m}$, a crest length of $1.481 \mathrm{~m}$ and a coronation width of $11,30 \mathrm{~m}$ with impervious core, filters and rock fill shoulders. More than 3 million $\mathrm{m}^{3}$ of materials were used for the construction, which started in April 2004 and finished in November 2006 with the first filling of the dam. It is used both for irrigation and energy production in the Guadalquivir basin. The Arenoso reservoir belongs to the Confederación Hidrográfica del Guadalquivir (CHG).

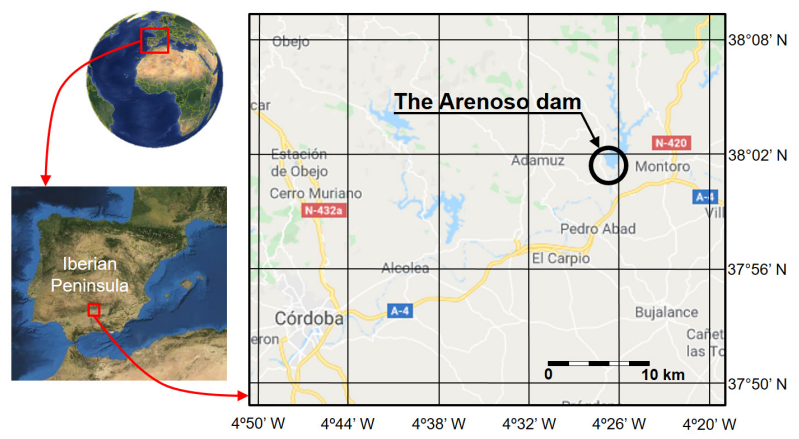

Figure 4: Location of The Arenoso dam in Montoro, province of Cordova (southern Spain).

In this case, we used Sentinel-1A/B C-band SAR data from the Interferometric Wide (IW) swath mode acquired using the Terrain Observation with Progressive Scan that allows wide area coverage with a size of $240 \mathrm{~km} \times 170 \mathrm{~km}$ per image. We selected the vertical polarization $\mathrm{VV}$ and processed two independent sets of Sentinel-1A/B SAR images acquired along ascending and descending orbits. The ascending set is from Track 74 and sub-swath 3 . It is composed by 194 SAR images (120 S1A and 74 S1B) from March $3^{\text {rd }}, 2015$ to February $28^{\text {th }}, 2019$. On the other side, the descending set belongs to Track 81 and sub- 
swath 3 as well. It is composed by 188 (116 S1A and 72 S1B) SAR images acquired from November $16^{\text {th }}, 2014$ to March $1^{\text {st }}, 2019$. The incidence angles in both sub-swaths are close to $44^{\circ}$. The spatial resolution for these SLC IW images with this incidence angle is $3.4 \times 22 \mathrm{~m}$ (range $x$ azimuth) with a ground sampling of $3.3 \times 13.9 \mathrm{~m}$ (range $x$ azimuth). For processing the data, we used the standard linear PS-InSAR technique to generate time series of deformation as implemented in SARPROZ.

Due to the characteristics of the region, fully covered by olive-tree plantings, almost no PS pixels were detected in the area surrounding the dam body, but a considerable density of coherent PS points over the dam allows the establishment of a long-term MT-InSAR monitoring system. Figure 5 shows the mean LOS velocity maps for both ascending and descending datasets. The general picture is quite similar. According to the depicted patterns, both tracks indicate the presence of a subsiding sector in the crest of the dam reaching linear values of the order of -(8-10) $\mathrm{mm} /$ year which represent cumulative displacement in the LOS direction up to about $-40 \mathrm{~mm}$ in 4 years. As both LOS velocity maps show a similar pattern, it could indicate that the main movement of the dam is in the vertical direction with little horizontal component, what is coherent with dam typology. Combining both ascending and descending LOS velocity maps, the displacement vector can be decomposed in the true horizontal E-W and vertical components. This decomposition can be seen in Figure 6 confirming that the main movement component of the dam is in the vertical direction (Ruiz-Armenteros et al. 2021).
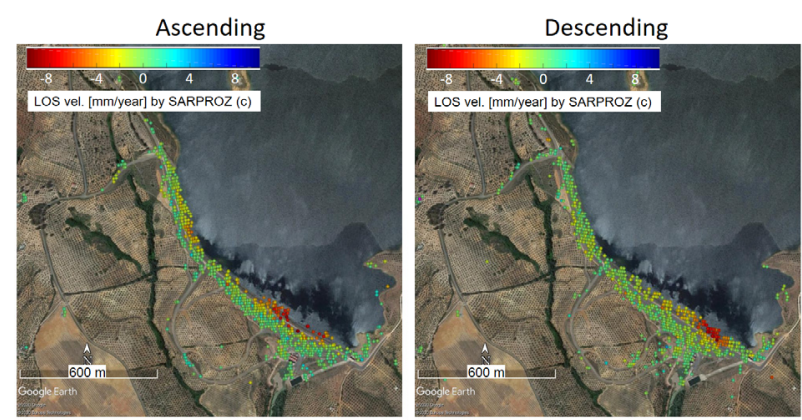

Figure 5: Mean LOS velocity for the ascending and descending datasets for The Arenoso dam in Montoro, province of Cordova (southern Spain), November 2014 - March 2019.

\subsection{Urban and aquifers monitoring}

Here we present two case studies centered in Valencia and Malaga (Spain) where some deformations were identified associated to aquifer overexploitation due to excesive use of groundwater, and others corresponding to local infraestructures.

\subsubsection{Valencia}

For this case, we used two datasets from the European Space Agency remote sensing satellites ERS-1/2 and Envisat to detect ground deformation in the northern sector of the Valencia basin (Valencia city and its surroundings), in east Spain, using PS-InSAR. 35 ERS1/2 SAR and 35 Envisat ASAR images were processed using the PSI standard approach with StaMPS. The ERS images were acquired between April 1993 and January 2000, along descending orbits (track 466), with an incidence angle of $23^{\circ}$ and a $5 \times 25 \mathrm{~m}$ nominal spatial resolution. The Envisat images were acquired between March 2003 and August 2010, along descending orbits as zell (same track as ERS-1/2), with an incidence angle of $23^{\circ}$ at the central middle swath IS 2 , and a $5 \times 25 \mathrm{~m}$ nominal pixel dimension.
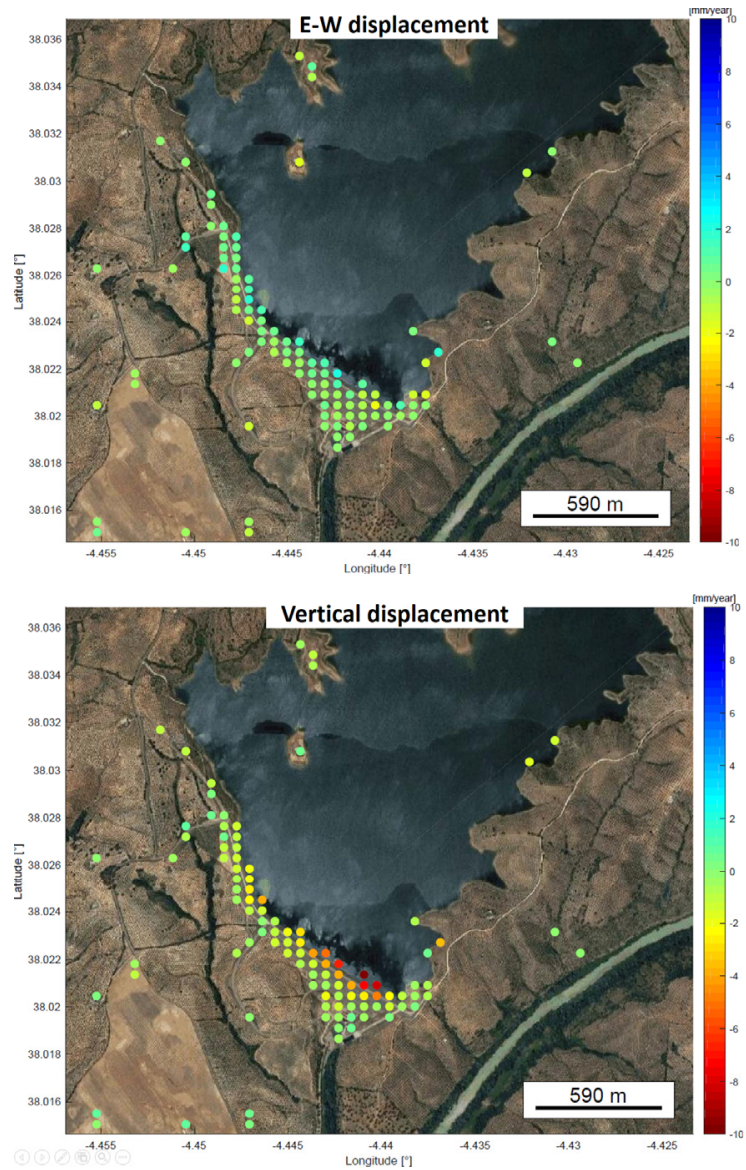

Figure 6: Mean velocity maps for the E-W and vertical displacements of the Arenoso dam in the period November 2014 - March 2019.

Figures 7 and 8 show the mean LOS velocities derived from ERS-1/2 (1993-2000) and Envisat (2003-2010) processing respectively. The ground motion estimated with PS-InSAR in the Valencia basin reveals some interesting subsidence patterns in three areas with rates up to $-5 \mathrm{~mm} /$ year (Ruiz-Armenteros et al. 2018b). The first is the Valencia harbor area (Fig. 9). In addition, some neighborhoods at the north and east of the harbor such as Benimaclet, Algirós, Poblados Marítimos, or the area of the Polytechnic University of Valencia show a subsiding behavior with a similar rate than in the harbor. The second area consists of a subsidence bowl located between $\mathrm{W}$ of Torrent and SE of Lorguilla villages (Fig. 10a). Particularly, it corresponds to a cultivated field area and also to industrial areas as those located in the north part (Oliveral Transmolbo) and in the east (NW of Torrente). Finally, the third area is located around $14 \mathrm{~km} \mathrm{NE}$ of Valencia city, between L'Eliana and San Antonio de Benagéber (Fig. 10b), and corresponds to residential areas. Most of the detected subsidence could be related to human induced activities such as excessive water consumption provoking over exploitation of aquifers and compaction of the ground. In any case, this is just a hypothesis and the causes of these subsidence patterns are being investigated. In the case of the harbor, some 
subsidences correspond to areas of recent anthropic landfill gained to the sea to expand port facilities. Currently, these areas are also being monitored using Sentinel-1A/B to detect the most recent displacements.

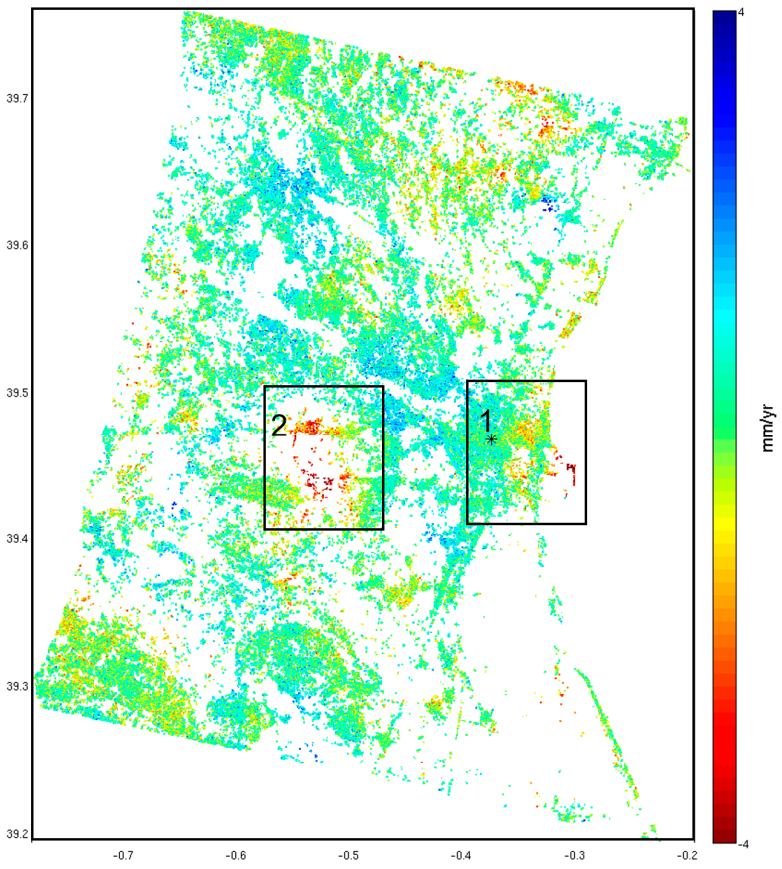

Figure 7: Mean LOS velocity from ERS-1/2 (1993-2000) in the Valencia basin.

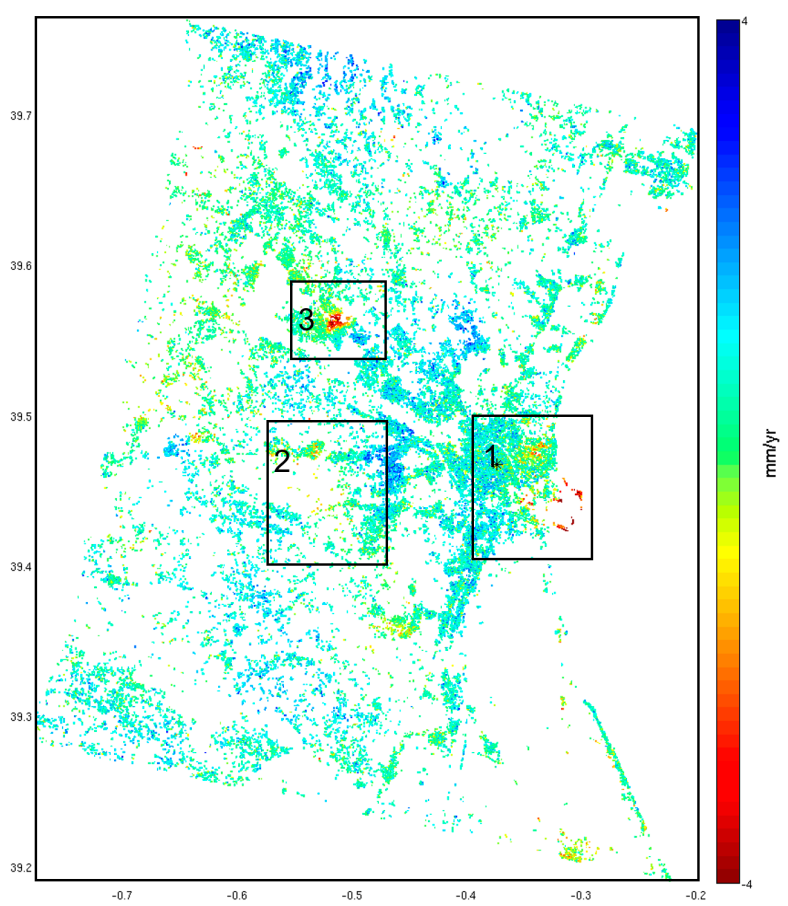

Figure 8: Mean LOS velocity from Envisat (2003-2010) in the Valencia basin.

\subsubsection{Malaga province}

In this case study, we analyzed the subsidence behavior of a coastal area in the province of Malaga (Costa del Sol), southern Spain, in the period 1992-2018 using Cband SAR interferometry. The area comprises several zones of interest where continuous deformation has happened during the analyzed period. Using SAR data from ESA ERS-1/2, Envisat, and Sentinel-1A/B satellites, and MT-InSAR methods we detected and monitored subsidence in highly populated and industrial areas, airport, harbor, as well as local instabilities over a railway line and a highway. In a previous work (Ruiz-Constán et al. 2018), we reported a subsidence due to intensive use of groundwater in some populated towns in this area in the period 1992-2009, with maximum line-of-sight (LOS) rates of the order of $-11 \mathrm{~mm} /$ year. Using Sentinel-1A/B data, we confirmed the subsidence trend of previous period. Furthermore, we detected an increase in the deformation rates for the most recent period (2014-2018), suggesting that the overexploitatin of the aquifers has not ceased.
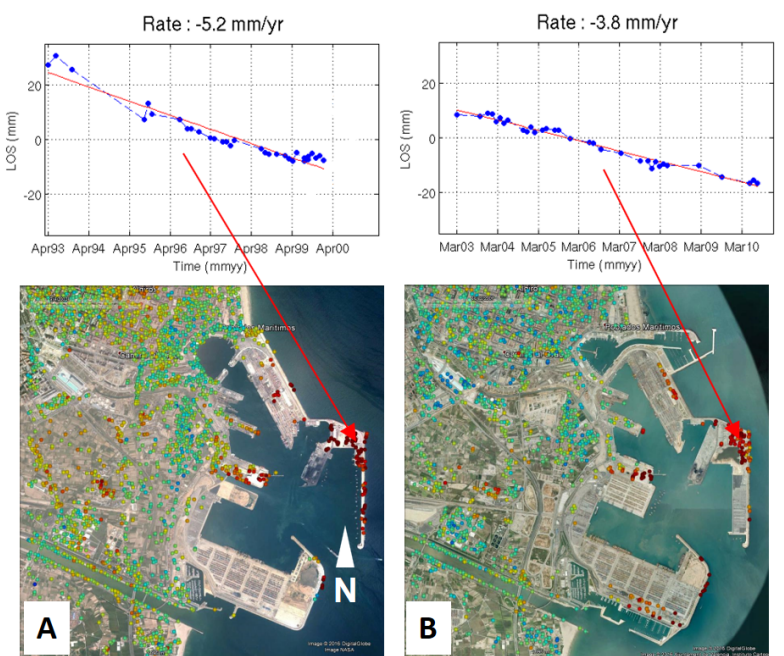

Mean LOS velocity $[\mathrm{mm} / \mathrm{yr}]$

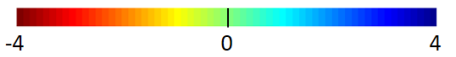

Figure 9: Mean LOS velocity from ERS-1/2 (A) and Envisat (B) in the Valencia harbor (right part of area 1 in Figures 7 and 8).

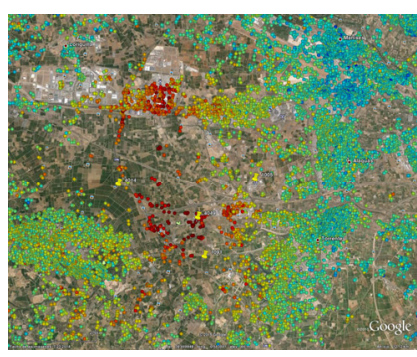

(a)

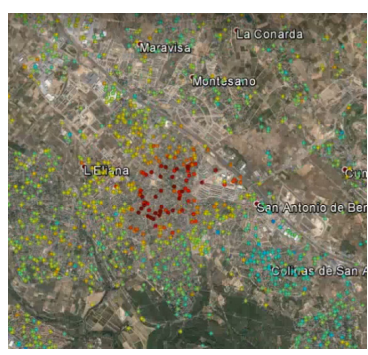

(b)
Figure 10: Mean LOS velocity from: a) ERS-1/2 between Torrent and Lorguilla villages (area 2 in Figure 7); b) Envisat between L'Eliana and San Antonio de Benagéber villages (area 3 in Figure 8). The color bar is the same than in Figure 9.

The SAR dataset used in this case was composed of 176 images acquired by three C-band ( $5,7 \mathrm{~cm}$ wavelength) satellites sensors, covering the total time period from May 1992 to February 2018. We used 30 ERS-1/2 SLC SAR images (ascending orbits, track 230) with an incident angle of $23^{\circ}$ and a $5 \times 25 \mathrm{~m}$ nominal spatial resolution (azimuth $x$ range), 20 Envisat ASAR images (ascending orbits - track 230), acquired with an incidence angle of $23^{\circ}$ at the middle swath IS2, and a $5 \times 25 \mathrm{~m}$ nominal pixel dimension (azimuth $x$ range), and 126 Sentinel-1A/B IW SLC SAR images (86 Sentinel-1A and 40 Sentinel-1B, 
acquired in descending orbits) with an incidence angle of $37-39^{\circ}$ in the center of sub-swath 2 and a pixel spacing of 2.3x14.1 m (range $x$ azimuth). ERS-1/2 and Envisat datasets were processed using StaMPS, more specifically its extended version (StaMPS-MTI) that includes the combination of PSI and SABS. Sentinel-1A/B data were processed using the PS-InSAR method implemented in SARPROZ and also using the IT4S1 aproach, where the data were specifically preprocessed using the InSAR Scientific Computing Environment (ISCE) and afterwards, the interferometric combinations were prepared for PSI processing using StaMPS (RuizArmenteros et al. 2018c).

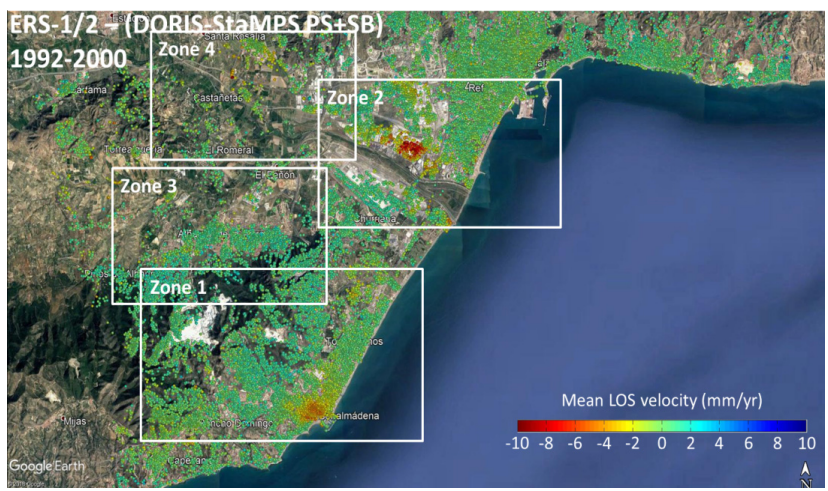

(a)

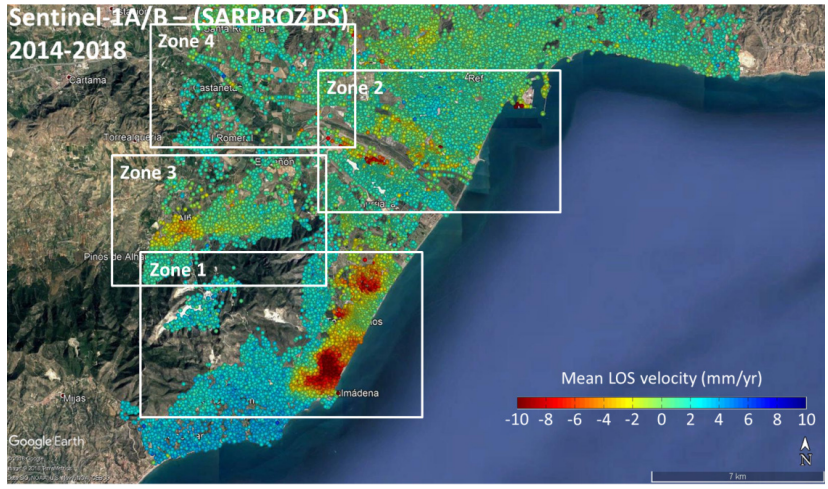

(c)
Figure 11 shows the mean LOS velocity maps derived from ERS-1/2 (1992-2000), Envisat (2003-2009), Sentinel-1A/B SARPROZ (2014-2018), and Sentinel$1 \mathrm{~A} / \mathrm{B}$ ISCE-StaMPS processing, related to the reference area located in the city of Málaga. In general, we found different subsiding areas but with different deforming rates depending on the analyzed period. The first area (zone 1 in Figure 11) corresponds to Torremolinos and Benalmádena towns close to the coast where we already presented the results of a subsidence bowl in this area for the period 1992-2009. Extending the analysis until 2018, we detected that the subsidence bowl has increased for the period 2014-2018, which denotes that an intensive use of the underground water could be still taking place.

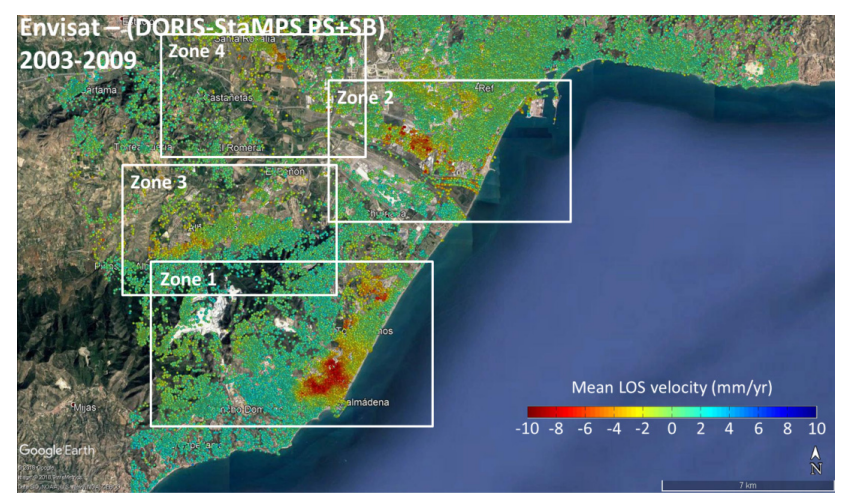

(b)

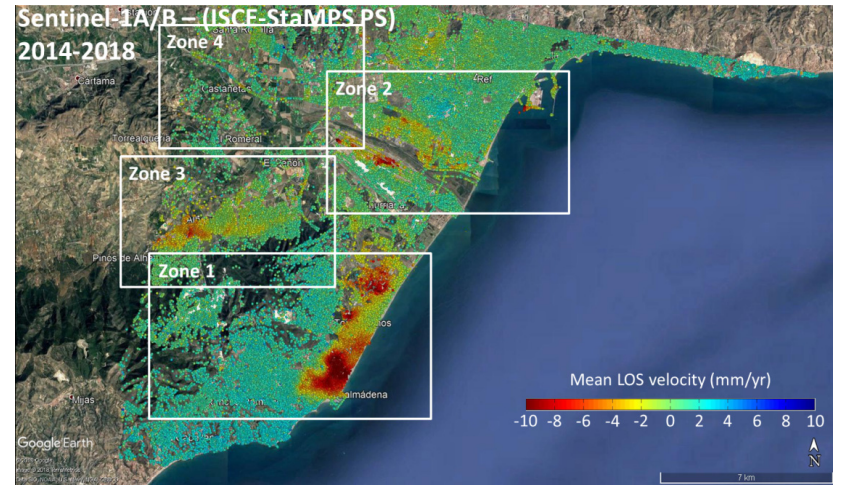

(d)

Figure 11: Mean LOS velocity maps for the study area. a) ERS-1/2 (1992-2000); b) Envisat (2003-2009); c) Sentinel-1A/B SARPROZ (2014-2018); d) Sentinel-1A/B ISCE-StaMPS.

The second area (zone 2 in Figure 11) reveals the subsidence occurred in the industrial area (Polígono Industrial Guadalhorce) located southwest of Malaga city. This can be clearly seen in the ERS-1/2 and Envisat periods but lately, it seems to be displaced to the south as it is evidenced by the Sentinel-1A/B analysis, affecting even the Malaga international airport (Málaga-Costa del Sol airport). In addition, we detected some subsidence in the harbor during the Envisat period, having been stabilized at a later time as it is evidenced by the Sentinel$1 \mathrm{~A} / \mathrm{B}$ analysis. However, a new small area appeared to be prone to subsidence, corresponding to the most recent reclaimed land for expanding port facilities.

Finally, the third area (zone 3 in Figure 11), revealed another subsidence bowl located in a residential area located in Alhaurín de la Torre village. As with Torremolinos-Benalmádena area, the deformation in Alhaurín de la Torre appears to be increasing with time as revealed by the evolution of the subsidence pattern during the three analyzed periods. Additionally, we detected a small subsidence, slightly with ERS-1/2 and increased with Envisat, between the north of Castañetas and east of Santa Rosalía, two neighborhoods of Málaga city $(20 \mathrm{~km}$ from the center) located in the district of Campanillas and very close to the banks of the Guadalhorce River (zone 4 in Figure 11). This subsidence now appears to have been stabilized in the Sentinel-1A/B period. Furthermore, during the last analyzed period (2014-2018), some inestabilities were detected in the railway line and in a highway near Málaga.

\section{Conclusions}

In this work, we present the applicability of satellite radar interferometry for deformation studies in geomatics engineering. Today, InSAR technology can be considered 
a consolidated technique whose effectivity for deformation studies has been widely proved in many cases. For infrastructure monitoring, if there is SAR data available of the study area, the technique is demonstrated to be of high value at a very low cost as compared with classical geodetic monitoring techniques. In case of other geotechnical or geodetic data are available, it can be successfully complemented.

We also illustrate the potential of SAR long time series scenes and the MT-InSAR technique for deformation monitoring in some important infrastructures such as dams, ports, transport lines, and urban constructions where the authors have identified deformation areas using medium resolution C-band SAR data from ERS-1/2, Envisat and Sentinel-1A/B satellites. The continuous processing of InSAR information could be successfully integrated in regular structural monitoring programs as a component of the implementation of early warning systems.

\section{Acknowledgements}

ERS-1/2 and Envisat datasets were provided by the European Space Agency (ESA). Sentinel-1A/B data were freely provided by ESA through Copernicus Programme. Data have been processed by DORIS (TUDelft), StaMPS (Andy Hooper), SARPROZ (Copyright (c) 2009-2020 Daniele Perissin), and SNAP (ESA). The satellite orbits are from TUDelft and ESA, as well as from the ESA Quality Control Group of Sentinel-1. Research was supported by [ESA Research and Service Support] for providing hardware resources employed in this work; [Spanish Ministry of Economy, Industry and Competitiveness] under ReMoDams project ESP201789344-R (AEI/FEDER, UE); [University of Jaén (Spain)] under PAIUJA-2021/2022 and CEACTEMA; [Junta de Andalucía (Spain)] under RNM-282 research group; [ ERDF through the Operational Programme for Competitiveness and Internationalisation - COMPETE 2020 Programme] within project «POCI-01-0145-FEDER006961»; [National Funds through the FCT - Fundação para a Ciência e a Tecnologia (Portuguese Foundation for Science and Technology)] as part of project UID/EEA/50014/2013; [The Ministry of Education, Youth and Sports from the National Programme of Sustainability (NPU II)] under project "IT4Innovations excellence in science - LQ1602» (Czech Republic); and [Slovak Grant Agency VEGA] under projects No. 2/0100/20.

\section{References}

ADAM, N., KAMPES, B., EINEDER, M., WORAWATTANAMATEEKUL, J., and KIRCHER, M., 2003. The development of a Scientific Permanent Scatterer System. ISPRS Hannover Workshop Proceedings.

ADAM, N., PARIZZI, A., EINEDER, M., and CROSETTO, M., 2009. Practical persistent scatterer processing validation in the course of the Terrafirma project. Journal of Applied Geophysics, 69(1), pp. 59-65.

BERARDINO, P., FORNARO, G., LANARI, R., and SANSOSTI, E., 2002. A new algorithm for surface deformation monitoring based on small baseline differential interferograms. IEEE Transactions on Geoscience and Remote Sensing, 40(11), pp. 2375-2383.

CROSETTO, M., ARNAUD, A., DURO, J., BIESCAS, E., and AGUDO, M., 2003. Deformation monitoring using remotely sensed radar interferometric data. Proc., 11th FIG Symposium on Deformation Measurements, Santorini.

CROSETTO, M., MONSERRAT, O., CUEVAS-GONZÁLEZ, M., DEVANTHÉRY, N., and CRIPPA, B., 2016. Persistent Scatterer Interferometry: A review. ISPRS Journal of Photogrammetry and Remote Sensing, 115, May, pp. 78-89.

FERRETTI, A., PRATI, C., and ROCCA, F., 2000. Nonlinear Subsidence Rate Estimation Using Permanent Scatters in Differential SAR Interferometry. IEEE Transactions on Geoscience and Remote Sensing, 38(5), pp. $2202-2212$.

FERRETTI, A., PRATI, C., and ROCCA, F., 2001. Permanent Scatters in SAR Interferometry. IEEE Transactions on Geoscience and Remote Sensing, 39(1), pp. 8-20.

FERRETTI, A., TAMBURINI, A., NOVALI, F., FUMAGAlLI, A., FALORNI, G., and RUCCI, A., 2011. Impact of high resolution radar imagery on reservoir monitoring. Energy Procedia, 39(1), pp. 8-20.

FERRETTI, A., 2014. Satellite InSAR Data: Reservoir Monitoring from Space, EAGE Publications.

HANSSEN, R.F., 2001. Radar Interferometry Data Interpretation and Error Analysis. Kluwer Academic Publishers, Dordrecht, $328 \mathrm{pp}$.

HOOPER, A., ZEBKER, H., SEGALL, P. and KAMPES, B., 2004. A new method for measuring deformation on volcanoes and other natural terrains using InSAR persistent scatterers. Geophysical Research Letters, 31(23). DOI:10.1029/2004GL021737

HOOPER, A., 2008. A multi-temporal InSAR method incorporating both persistent scatterer and small baseline approaches. Geophysical Research Letters, 35, L16302.

HOOPER A., BEKAERT D., SPAANS K., and ARIKAN M., 2012. Recent advances in SAR interferometry time series analysis for measuring crustal deformation. Tectonophysics, 514, pp. 1-13. DOI: 10.1016/j.tecto.2011.10.013

HO TONG MINH, D., HANSSEN, R., and ROCCA, F., 2020. Radar Interferometry: 20 years of Development in time series techniques and future perspectives. Remote Sensing, 12, 1364. DOI:10.3390/rs12091364

KAMPES, B., 2005. Displacement parameter estimation using permanent scatterer interferometry. Ph. D. Dissertation, Delft University of Technology, Delft, The Netherlands. 
Ruiz-Armenteros, Delgado-Blasco, Bakon, Lazecky, Marchamalo-Sacristán, Lamas-Fernández, Ruiz-Constán, Galindo-Zaldívar, Sanz de Galdeano, Martos-Rosillo, Papco, Perissin, Sousa, 2021

LANARI, R., MORA, O., MANUNTA, M., MALLORQUI, J.J., BERARDINO, P., and SANSOSTI, E., 2004. A small-baseline approach for investigating deformations on full-resolution differential SAR interferograms. IEEE Transactions on Geoscience and Remote Sensing, 42(7), pp. 1377-1386.

LANARI, R., CASU, F., MANZO, M., ZENI, G., BERARDINO, P., MANUNTA, M., and PEPE, A., 2007. An overview of the small baseline subset algorithm: a DInSAR technique for surface deformation analysis. Pure and Applied Geophysics, 164(4), pp. 637-661.

LYONS, S., and SANDWELL, D., 2003. Fault creep along the southern San Andreas from interferometric synthetic aperture radar, permanent scatterers, and stacking. Journal of Geophysical Research, 108(B1), pp. 2047-2070.

MARINKOVIC, P., KETELAAR, V.B.H., VAN LEIJEN, F.J., and HANSSEN, R.F., 2008. InSAR quality control: analysis of five years of corner reflector time series. In: Fifth International Workshop on ERS/Envisat SAR Interferometry, 'FRINGE07', Frascati, Italy, 26 Nov-30 Nov 2007, Noordwijk, pp. 1-8. ESA Communication Production Office.

MARINKOVIC, P, and LARSEN, Y., 2016. Mapping and analysis of the Central Italy Earthquake (2016) with Sentinel-1 A/B interferometry. Zenodo. DOI 10.5281/zenodo.61133

OSMANOĞLU, B., SUNAR, F., WSOWINSKI, S., and CABRAL-CANO, E., 2016. Time series analysis of InSAR data: Methods and trends. ISPRS Journal of Photogrammetry and Remote Sensing, 115, May, pp. 90-102.

PELTIER, A., BIANCHI, M., KAMINSKI, E., KOMOROWSKI, J.-C., A. RUCCI, and STAUDACHER, T., 2010. PSInSAR as a new tool to monitor pre-eruptive volcano ground deformation: Validation using GPS measurements on Piton de la Fournaise. Geophysical Research Letters, 37, L12301. DOI: 10.1029/2010GL043846

PERISSIN, D. and WANG, T., 2012a. Repeat-pass SAR interferometry with partially coherent targets. IEEE Transactions on Geoscience and Remote Sensing, 50, pp. 271-280.

PERISSIN, D. and WANG, T., 2012b. Time-series InSAR applications over urban areas in China. IEEE Journal of Selected Topics in Applied Earth Observations and Remote Sensing, 4(1), pp. 92-100.

PERISSIN, D., 2015. "SARPROZ software". SARPROZ @ - The SAR PROcessing tool by periZ. Available: https://www.sarproz.com/ [7/02, 2021]

ROSEN, P., HENSLEY, S., JOUGHIN, I., LI, F., MADSEN, S., RODRIGUEZ, E., and GOLDSTEIN, R., 2000. Synthetic aperture radar interferometry. In: Proceedings of the IEEE, 88(3), pp. 333-382.

RUIZ-ARMENTEROS, A.M., LAZECKY, M., HLAVÁČOVÁ, I., BAKOŇ, M., DELGADO, J.M., SOUSA, J.J., LAMASFERNÁNDEZ, F., MARCHAMALO, M., CARO-CUENCA, M., PAPCO, J., and PERISSIN, D., 2018a. Deformation monitoring of dam infrastructures via spaceborne MT-InSAR. The case of La Viñuela (Málaga, southern Spain). Procedia Computer Science, 138, pp. 346-353. DOI: 10.1016/j.procs.2018.10.049

RUIZ-ARMENTEROS, A.M., DELGADO, J.M., BALLESTEROS-NAVARRO, B.J., LAZECKY, M., BAKON, M., and SOUSA, J.J., 2018b. Deformation Monitoring of the Northern Sector of the Valencia Basin (E Spain) Using PS-InSAR (1993-2010). Proceedings of IGARSS 2018 - 2018 IEEE International Geoscience and Remote Sensing Symposium, pp. 2244-2247.

RUIZ-ARMENTEROS, A.M., LAZECKY, M., RUIZ-CONSTÁN, A., BAKOŇ, M., DELGADO, J.M., SOUSA, J.J., GALINDOZALDÍVAR, J., SANZ DE GALDEANO, C., CARO-CUENCA, M., MARTOS-ROSILLO, S., JIMÉNEZ-GAVILÁN, P., and PERISSIN, D., 2018c. Monitoring continuous subsidence in the Costa del Sol (Málaga province, southern Spanish coast) using ERS-1/2, Envisat, and Sentinel-1A/B SAR interferometry. Procedia Computer Science, 138, pp. 354-36. DOI: 10.1016/j.procs.2018.10.050

RUIZ-ARMENTEROS, A.M., MARCHAMALO-SACRSITÁN, M., BAKON, M., LAMAS-FERNÁNDEZ, F., DELGADO, J.M., SÁNCHEZ-BALLESTEROS, V., PAPCO, J., GONZÁLEZ-RODRIGO, B., LAZECKY, M., PERISSIN, D., and SOUSA, J.J., 2021. Monitoring of an embankment dam in southern Spain based on Sentinel-1 Time-series InSAR. Procedia Computer Science, 181, pp. 353-359. DOI: 10.1016/j.procs.2021.01.178

RUIZ-CONSTÁN, A., RUIZ-ARMENTEROS, A.M., MARTOS-ROSILLO, S., GALINDO-ZALDÍVAR, J., LAZECKY, M., GARCÍA, M., SOUSA, J.J., SANZ DE GALDEANO, C., DELGADO-BLASCO, J.M., JIMÉNEZ-GAVILÁN, P., CAROCUENCA, M., and LUQUE-ESPINAR, J.A., 2018. "SAR interferometry monitoring of subsidence in a detritic basin related to water depletion in the underlying confined carbonate aquifer (Torremolinos, southern Spain)". Science of the Total Environment, 636, pp. 670-687.

USAI, S., 1997. The use of man-made features for long time scale INSAR. Geoscience and Remote Sensing, 1997. IGARSS '97. Remote sensing - A scientific vision for sustainable development, 1997. IEEE International, 4, pp. 15421544.

USAI, S., and HANSSEN, R., 1997. Long time scale INSAR by means of high coherence features. 3rd ERS Symposium on Space at the service of our Environment, Florence, Italy, 14-21 March, European Space Agency.

ZHONG, L., JIXIAN, Z., YONGHONG, Z., and DZURISIN, D., 2010. Monitoring and characterizing natural hazards with satellite InSAR imagery. Journal Annals of GIS, 16(1), pp. 55-66. 